\title{
Contribution of SERCA and IP3 sensitivity to calcium signaling in astrocytes: a computational study
}

\author{
Eeva Toivari ${ }^{1 *}$, Katri Hituri ${ }^{1}$, Tiina Manninen ${ }^{1}$, Tuula O Jalonen ${ }^{2}$, Marja-Leena Linne ${ }^{1 *}$ \\ From Twentieth Annual Computational Neuroscience Meeting: CNS*2011 \\ Stockholm, Sweden. 23-28 July 2011
}

Modeling the mechanisms of astrocytic calcium signals is important, as astrocytes have an essential role in regulating the neuronal microenvironment of the central nervous system $[1,2]$. The results of the wet-lab and clinical studies can be complemented by mathematical models to gain better understanding of the complex molecular level interactions seen, for example, in the pathogenesis of Alzheimer's disease (AD). In the aging brain astrocytes are known to change their phenotype [3], also their ionic equilibrium and function can be altered by the interaction of released and accumulated transmitters and peptides, such as, amyloid- $\beta$ peptides $[A \beta, 4]$. The authors have recently shown, experimentally and computationally, that small amounts of A $\beta 25-35$ fragment amplify the transmitterinduced calcium signals in astrocytes [5]. The reason for the amplification may be changes in calcium release from endoplasmic reticulum (ER) via, for example, changes in the function of sarco(endo)plasmic calcium adenosine 5 '-triphosphatase (SERCA) pumps and/or in intracellular inositol 1,4,5-trisphosphate (IP3) sensitivity [6]. Mutations in presenilin 1 (one of the factors in familial AD involved in the accumulation of $A \beta$ fragments in the brain) may change the activity of the SERCA, which pumps the cytosolic calcium into the ER lumen, leading eventually to higher concentration of calcium in ER [6]. Thus, the current hypothesis is that exceptional cytosolic calcium signals via ER, overfilled with calcium, may explain the calcium changes detected in the presence of $\mathrm{A} \beta$.

\footnotetext{
* Correspondence: eeva.toivari@tut.fi

'Department of Signal Processing, Tampere University of Technology, P.O. Box 553, Fl-33101 Tampere, Finland

Full list of author information is available at the end of the article
}

We here study the effect of SERCA pumps and IP3 sensitivity on calcium signals in astrocytes by further exploring the existing deterministic [7] and stochastic [5] models to explain the altered calcium regulation. The models include the six major mechanisms known to be involved in calcium signaling in astrocytes; 1 ) calcium leak from/to extracellular matrix (ECM), 2) capacitive calcium entry from ECM, 3) calcium entry via ionotropic receptors, 4) calcium leak from intracellular stores, such as ER, 5) storage of calcium to ER via SERCA pumps, and 6) calcium release from ER mediated by IP3. In this study, we computationally explore and verify the role of SERCA pump and IP3 sensitivity -induced changes in intracellular calcium signals experimentally shown in [8] and [9]. The understanding of calcium signals in astrocytes is essential as the changes in astrocytic calcium signaling are prone to cause widespread alterations in neuronal network function and can lead to neurological disorders.

\section{Acknowledgements \\ This study was supported by the Academy of Finland, application numbers 126556 and 129657 (Finnish Programme for Centres of Excellence in Research 2006-2011.}

\section{Author details}

'Department of Signal Processing, Tampere University of Technology, P.O. Box 553, Fl-33101 Tampere, Finland. ${ }^{2}$ Department of Physiology and Neuroscience, St. George's University, School of Medicine, Grenada, West Indies.

Published: 18 July 2011

\footnotetext{
References

1. Kimelberg HK, Jalonen T, Walz W: Regulation of the Brain Microenvironment: Transmitters and lons. In Astrocytes: Pharmacology and Function. Academic Press Inc.;S. Murphy 1993:193-228.

2. Seifert G, Schilling K, Steinhäuser C: Astrocyte dysfunction in neurological disorders: a molecular perspective. Nature 2006, 7:194-206.
} 
3. Simpson JE, Ince PG, Lace G, Forster G, Shaw PJ, Matthews F, Savva G, Brayne C, Wharton SB: Astrocyte phenotype in relation to Alzheimer-type pathology in the ageing brain. Neurobiol. Aging 2010, 31:578-590.

4. Casley CS, Lakics V, Lee H, Broad LM, Day TA, Cluett T, Smith MA, O'Neill MJ, Kingston AE: Up-regulation of astrocyte metabotropic glutamate receptor by amyloid- $\beta$ peptide. Brain Res 2009, 1260:65-75.

5. Toivari E, Manninen T, Nahata AK, Jalonen TO, Linne ML: Effects of Transmitters and Amyloid-beta Peptide on Calcium Signals in Rat Cortical Astrocytes: Fura-2AM Measurements and Stochastic Model Simulations., Accepted to PLOS ONE.

6. Leissring MA, Akbari Y, Fanger CM, Cahalan MD, Mattson MP, LaFerla FM: Capacitative calcium entry defi-cits and elevated luminal calcium content in mutant presenilin-1 knockin mice. J. Cell Biol 2000, 149:793-797.

7. Di Garbo A, Barbi M, Chillemi S, Alloisio S, Nobile M: Calcium signalling in astrocytes and modulation of neural activity. BioSystems 2007, 89:74-83.

8. Green KN, Demuro A, Akbari Y, Hitt BD, Smith IF, Parker lan, LaFerla FM: SERCA pump activity is physio-logically regulated by presenilin and regulates amyloid $\beta$ production. J. Cell Biol 2008, 181(7):1107-1116.

9. Morita M, Kudo Y: Growth Factors Upregulate Astrocyte $\left[\mathrm{Ca}^{2+}\right]_{\mathrm{i}}$ Oscillation by Increasing SERCA2b Expression. Glia 2010, 58:1988-1995.

doi:10.1186/1471-2202-12-S1-P201

Cite this article as: Toivari et al:: Contribution of SERCA and IP3 sensitivity to calcium signaling in astrocytes: a computational study. BMC Neuroscience 2011 12(Suppl 1):P201.

\section{Submit your next manuscript to BioMed Central} and take full advantage of:

- Convenient online submission

- Thorough peer review

- No space constraints or color figure charges

- Immediate publication on acceptance

- Inclusion in PubMed, CAS, Scopus and Google Scholar

- Research which is freely available for redistribution

Submit your manuscript at www.biomedcentral.com/submit
Biomed Central 